\title{
Mathematic Model Design Of Solar Pumping For Drip Irrigation Systems
}

\author{
Mhamdi Hicham*, Omar Kerrou, Ahticha Mohamed, Azeddine Frimane, Aggour Mohamed \\ Laboratory of Electronic Systems, Information Processing, Mechanics and Energetics, Faculty of Sciences \\ Kenitra, University Ibn Tofail Kenitra, Kenitra, Morocco \\ *Mail: hicham.mhamdi@uit.ac,ma \\ Postal address: Ibn Tofail University, Faculty of Sciences, University campus, BP: 133, Kenitra, Morocco
}

Article History: Received:11 January 2021; Accepted: 27 February 2021; Published online: 5 April 2021

\begin{abstract}
The use of solar energy in isolated sites for different applications, such as water pumping, is of primary interest to people in developing countries who do not have safe access to water drinking. But photovoltaic generators have two major drawbacks that are a low yield and a high blow. In order to increase the performance of these systems. Proper adaptation between the solar generator and the load reduces the cost of installation. The choice of an energy system must obey and comply with certain rules. The selected energy system must show as a preliminary its competitiveness with respect to other systems for the same rendered service. The present study have a propose the modeling, simulation, sizing and realization of a photovoltaic pumping system operating over the sun. This system consists of a set of interacting elements; namely the photovoltaic panels, the voltage inverter, the asynchronous motor, the centrifugal pump and the hydraulic circuit.
\end{abstract}

Keywords: Photovoltaic panels, Solar energy, emitter, converter

\section{Introduction}

Energy consumption is growing at a rate of approximately $1 \%$ per year, and at a rate of $5 \%$ per year in developing countries [1-3]. The energy demand is increasing every day, and petroleum based fuels are not promoted to compensate that growing demand, mainly because of decreasing world petroleum production and environmental pollution such as greenhouse effect and global warming [4-8]. Due to the increasing world energy demand, rising cost of fossil fuel, increasing

concerns about environmental pollution, and uncertainty about the costs and availability of fossil fuels in the future, use of renewable energy will probably increase and can be economically acceptable in the future

[9-12]. Renewable sources play a vital role

In sustainable development and environmentally friendly energy sources [13-15]. Among all renewable energy sources, Solar energy is the best source of free, available, and clean energy for the environment.

Water pumping in developing countries is generally dependent on conventional electricity or diesel generated electricity. Solar water pumping system is to reduces the usage of diesel fuel or coal based electricity. The use of diesel based water pumping systems requires not only expensive fuels, but also create noise and air pollution. Overall upfront cost, operating and maintenance costs, and diesel pump replacement are 2-4 times higher than a solar photovoltaic (PV) pump. Environment friendly solar pumping systems require less maintenance cost with no fuel cost [16]. Keeping in view the shortage of electricity

in rural villages, PV pumping is one of the most promising applications of solar energy. This technology is similar to any other conventional water pumping system except that the power source is solar energy. PV water pumping is gaining importance in recent years due to non-availability of electricity and increase in diesel prices [17]. The flow rate of pumped water is dependent on incident solar radiation and size of PV array. A properly designed PV system results in significant longterm cost savings as compared to conventional pumping systems [18]. This paper discusses about the combined effect of solar power pump connected with the emitter system.

\section{Literature review}


According to the survey conducted by the Bureau of Electrical Energy in morocco in 2017, there are around 7 million pump sets and around 0.5 million new connections per year is installed with average of $3 \mathrm{HP}$ capacity for agricultural purpose [19]. Solar PV technology applied to water pumping systems is based on the conversion of solar energy into electrical energy by solar panels to power a water pump [20]. PV panels are connected to a Direct Cur- rent (DC) or Alternating Current (AC) motor that converts the electrical energy received from the panels into mechanical energy and is subsequently converted into hydraulic energy [21]. Proper selection and design of PV technology for water pumping systems for irrigation and its components are essential for the stability and efficiency of the systems. Solar powered smart irrigation technique is the future for the farmers and a solution for the energy crisis[22].

\section{Methodology :}

Emitter connected with D.C water pump is used for irrigation purpose. The pump will increase the water pressure in the dripper ( emitter ) water bike. Thus, emitter rotates its maximum speed so that the water will flow from the dripper to the crop in a way that ensures that the roots are well watered .. The pump is also used to store the water in the storage tank for later use. The pump will be operated with the power supply from the solar panel. The converter is used between the solar panel and water pump. The converter also used to charge the battery [23]. Battery is used to supply energy to the pump during the irrigation process at night time. The simple layout of solar PV irrigation system is shown in Figure 1. The major components used for this solar PV irrigation system are Solar panel, Converter, Transformer, Pump and Battery. The detailed specification of the components used are listed in Table 1.

\subsection{Solar panel}

The solar panel consists of a PV (Photovoltaic) cell. Figure 2 shows the solar panel used for irrigation system. The cells shown in solar panel were made of semiconductor materials. When the sunlight strikes the cell, the positive terminals will move on one side and negative cells move another side and then electrons are activated and are stored in the battery as DC current. Most of the solar panels or modules generate direct current (DC). Then the generated cur- rent is supplied to converter [25]. This power can be used both purposes, to operates the pump and also to store it in the battery for later use. The PV cell is more cost-effective for power generation when compared with other electrical grid or using the generators. The PV electrical system is an eco-friendly system and more suitable for villages and remote areas.

The installation of this system is very low cost compared to the other power generation system installation. The power generation cost for this system is nil [26]. There is no cost is spending for power generation but installation cost is needed. This natural power supply system is eco-friendly,

Table1 : Specification of Components.

\begin{tabular}{lll}
\hline Name of the component Capacity & Quantity \\
Solar panel & $150 \mathrm{~V}$ & 2 \\
Convertor & $240 \mathrm{~V}$ & 1 \\
Transformer & $240 \mathrm{~V}$ & 1 \\
Pump & $240 \mathrm{~V}$ & 1 \\
Battery & $150 \mathrm{Ah}$ & 1 \\
Emitter & & $21 / \mathbf{h}, \mathbf{4 1 / h}$ \\
& & \\
\hline
\end{tabular}




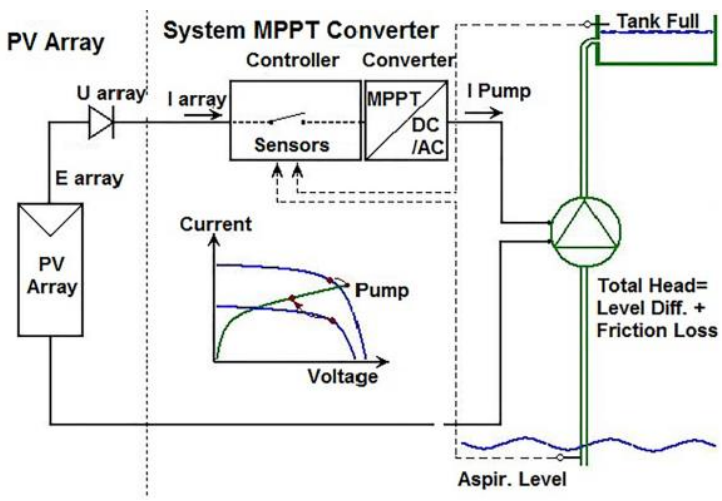

Figure1. System schematic.

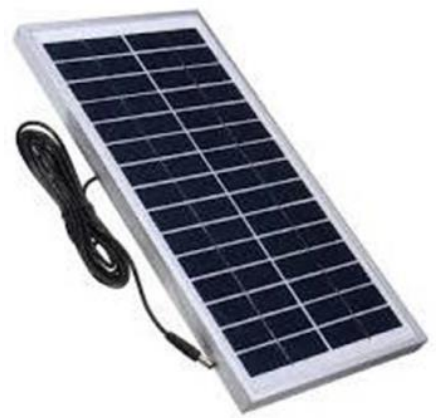

Figure 2 : solar panel

Therefore zero pollution for this type of power generation. This solar panel produces normally $220 \mathrm{~V}$ to $250 \mathrm{~V}$ capacity.

\subsection{Converter}

A solar converter is a common inverter which uses solar energy. This inverter is used to change the DC into AC using solar power [27]. A solar inverter is used to operate many devices that run on DC power to run on AC power. The basic function of the inverter is to change the variable Direct Current output of the solar panels into Alternating Current. Figure 3 shows the solar converter. It also used to control the flow of current. It will help to store the D.C power supply to the battery at the meantime it also helps to operate the pump [28].

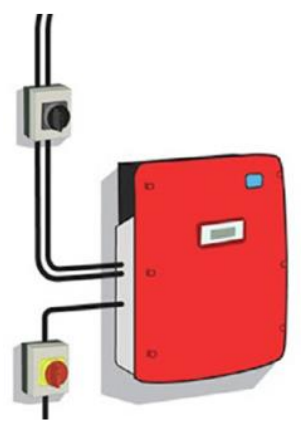

Figure3: converter. 
The transformer is used to balance the power. The transformer used for this work shown in Figure 4. When the power generation is low because of poor sunlight, the energy from the sun will be low. When the power production is less at that time the transformer will step up the power and balance the output supply and vice versa [29]. The transformer will be used for both step-up and step-down process. The transformer plays a major role to run the pump. The transformer circuit is shown in Figure 5.

\subsection{Pump and discharge line}

The water pump used for this system shown in the Figure 6. DC pumps are classed as either displacement or centrifugal and can be either submersible or surface types. The pump will be operated with $220 \mathrm{~V}$ by using the solar panel. The pump will be used for dual purpose, one is to push the water in the emitter pipe to increase the pressure of the water so that water will be run evenly and the second one is to store water in water storage tank if needed for later purpose [30]. A $220 \mathrm{~V}$ power supply is required to operate the pump.

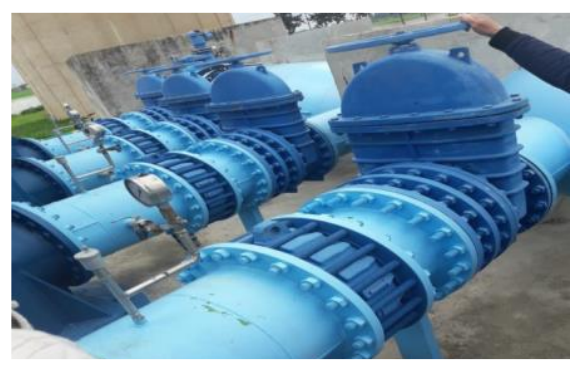

Figure4: discharge line

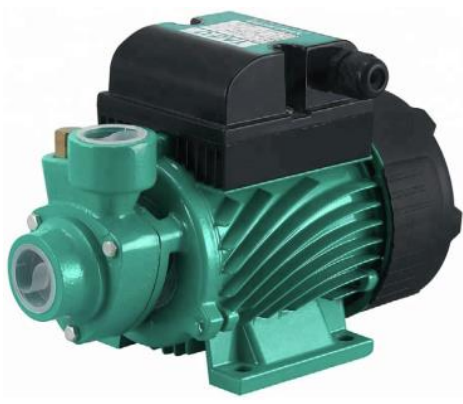

Figure5: DC water pump

The battery is used to store the power supply from the converter. But it is not recommended to operate the pump, because the pump can be operated directly by using the solar panels with the help of the converter. The battery is used during night time usage of the drip irrigation system in the cultivation lands [31]. It is also used to operate the pump to carry out water during day time. The battery capacity is $150 \mathrm{Ah}$. The solar panel will produce variable current according to the lighting of the sun. The solar

panel normally produce 220 to $250 \mathrm{~V}$ it takes $6 \mathrm{hr}$ to fully charge the battery and the run time of the pump is $3 \mathrm{hr}$ when fully charged. During night the water is stored in the high level take with the help of battery operated pump [32]. The battery used for solar operated irrigation system is shown in Figure 7.

The pumping units are equipped at their outlets with discharge lines comprising free expansion 
joints, non-return valves and isolating valves. The assembly leads to a discharge manifold consisting of three sections, supported by reinforced concrete stops.

\subsection{Emitter}

The emitter is used to minimize the water usage for cultivation, garden and in buildings as a fire emitter to off the fire in buildings. The emitter used in this work is shown in Figure 8. The emitter is working based on the pressure of the water [33]. The working emitter is shown in the Figure 9.

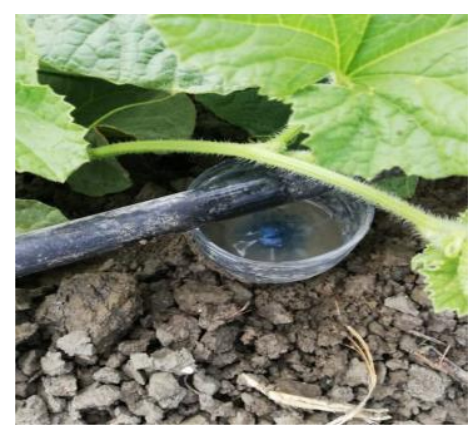

Figure 6: Emitter

\subsection{Simulation using PVsyst software}

Table 2: Location and water resource information.

Name of location for system installation SA TAZI, morocco

$\begin{array}{ll}\text { Latitude } & 34.46{ }^{\circ} \mathrm{N} \\ \text { Longitude } & -6.28{ }^{\circ} \mathbf{E} \\ \text { Altitude } & 980 \mathrm{~m}\end{array}$

Name of water resource system Deep well to storage

Application for which system used Irrigation

Well diameter $\quad 10 \mathrm{~cm}$

Static level depth $\quad 50 \mathrm{~m}$

Pump depth $60 \mathrm{~m}$

Max. pumping depth $\quad 55 \mathrm{~m}$

\subsubsection{Details of pump, water storage tank and pumping network}

Table 3 presents about details of pump, water storage tank and pumping system

\subsubsection{Details of photovoltaic array}

Table 4 provides the detailed information of PV cell and PV array.

\subsubsection{Monthly climate data of the location}

The climate data includes details of beam radiation, horizontal 
Table 3: Pumping system details

Type of pump Centrifugal multistage

\begin{tabular}{ll}
\hline Specification about motor & DC motor, Brushless \\
Power rating & $3750 \mathrm{~W}$ \\
Name of manufacturer & Grundfos \\
Volume of storage tank & $30 \mathrm{~m}^{3}$ \\
Water requirement & $30 \mathrm{~m}^{3}$ \\
Day of autonomy & $\mathbf{0 ~ d a y s}$ \\
Diameter & $3.2 \mathrm{~m}$ \\
Height & $3.7 \mathrm{~m}$ \\
Feeding altitude & $4 \mathrm{~m}$ \\
Total length of pipe & $\mathbf{8 0 ~ m}$ \\
Size of pipe & $2^{10}$ \\
No. of elbows used & 1
\end{tabular}

Table4: Information about PV array.

Name of manufacturer Alex Solar

Model no. or name

ALP150-24

Type of solar cell Si-poly

No. of PV modules 32

No. of modules in series 8

No. of modules in parallel 4

Power rating of per unit module $150 \mathrm{~W}$

Voltage ratings $\quad 34.7 \mathrm{~V}\left(\mathrm{~V}_{\mathrm{mpp}}\right)$

Current ratings $\quad 4.35 \mathrm{~A}\left(\mathrm{I}_{\mathrm{mpp}}\right)$

Total power capacity of PV array $4800 \mathrm{~W}$

Total area of PV array $\quad 40.9 \mathrm{~m}^{2}$

\subsection{Simulation using PVsyst software}

\subsection{PVsyst results}

\subsubsection{Outputs of system design calculation}

The system efficiency from PVsyst is $82.5 \%$ and it shows that designed system has valuable performance with selection of different parameters. 
The results show that most of energy generated from PV array is used by the pumping system and only $11.7 \%$ fraction of total generated energy is wasted. The water pumping cost from this design is 0.052 USD per $\mathrm{m}^{3}$ and this amount is very less in comparison to diesel pumpset (Table 6).

\subsubsection{System schematic}

This schematic design is generated by PVsyst software and has details of interconnection of the all needed components of solar water pump. Performance of system is also explained with the help of V-I characteristic and power curve (Figure 1).

1.3.3. Reference incident energy

This graph of reference incident energy shows average solar irradiance per month without considering losses at standard test conditions (Figure 7). Performance ratio (PR)

It is the ratio of actual yield of PV system to the reference yield.

For this design performance ratio (PR) is obtained 0.631. The Performance ratio includes the optical losses (Shadings, IAM, Soiling), the array losses (PV conversion, ageing, module quality, mismatch, wiring, etc.) and the system losses (inverter efficiency in grid connected or storage/battery/unused losses in stand-alone, etc.) (Figure 8).

Table 5. Monthly climatic data.

\begin{tabular}{|c|c|c|c|c|}
\hline Month & $\begin{array}{l}\text { Global } \\
\text { Horizontal } \\
\left(\mathbf{k W h} / \mathbf{M}^{2}\right) \\
\end{array}$ & $\begin{array}{l}\text { Beam } \\
\text { Radiation } \\
\left(\mathbf{k W h} / \mathbf{M}^{2}\right) \\
\end{array}$ & $\begin{array}{l}\text { Diffuse } \\
\text { Radiation } \\
\left(\mathbf{k W h} / \mathbf{M}^{2}\right) \\
\end{array}$ & $\begin{array}{l}\text { Ambient } \\
\text { Temperature }\left({ }^{\circ} \mathbf{C}\right)\end{array}$ \\
\hline January & 103.4 & 72,52 & 30.88 & 13.60 \\
\hline February & 104.6 & 65,39 & 39.21 & 14.1 \\
\hline March & 136 & 73,79 & 62.21 & 15.9 \\
\hline April & 172 & 108,75 & 63.25 & 17.1 \\
\hline May & 169.7 & 100 & 69.70 & 19.8 \\
\hline June & 228.7 & 167,4 & 61.30 & 23.2 \\
\hline July & 227.3 & 159,6 & 67.7 & 26.1 \\
\hline August & 202.6 & 136,08 & 66.52 & 26 \\
\hline September & 157.5 & 100,3 & 57.20 & 23.6 \\
\hline October & 144.2 & 79,8 & 64.40 & 20.7 \\
\hline November & 133.8 & 105,08 & 28.72 & 16.4 \\
\hline December & 115.5 & 89,62 & 25.88 & 4.3 \\
\hline
\end{tabular}

Table 6 . Main Simulation Results of PV Sys

\begin{tabular}{|c|c|c|}
\hline System Production & $\begin{array}{l}\text { Water Pumped - } \\
10629 \mathrm{~m}^{3} \text { Water } \\
\text { needs }-10,950 \mathrm{~m}^{3} \\
\text { Energy at Pump - } \\
6547 \mathrm{kWh} \\
\text { Unused PV energy(Tank Full)-927 kWh }\end{array}$ & $\begin{array}{l}\text { Specific - } 365 \\
\mathrm{~m}^{3} / \mathbf{k W p} / \mathrm{bar} \\
\mathrm{Missing} \mathrm{Water} \mathrm{-} \text {-9\% Specific - } \\
0.62 \mathrm{kWh} / \mathrm{m}^{3} \\
\text { Unused Fraction - } \\
11.7 \%\end{array}$ \\
\hline Investment & $\begin{array}{l}\text { System Efficiency }-82.5 \% \\
\text { Global incl. taxes }-3.15 \text { USD }\end{array}$ & $\begin{array}{l}\text { Specific - } 0.66 \\
\text { USD/Wp }\end{array}$ \\
\hline
\end{tabular}


Yearly

Cost

Specific

Cost
Annuities (Loan 12.0\%, 20 years)-

421.35USD/yr

$0.052 \mathrm{USD} / \mathrm{m}^{3}$
Running Costs 136.65USD /yr 


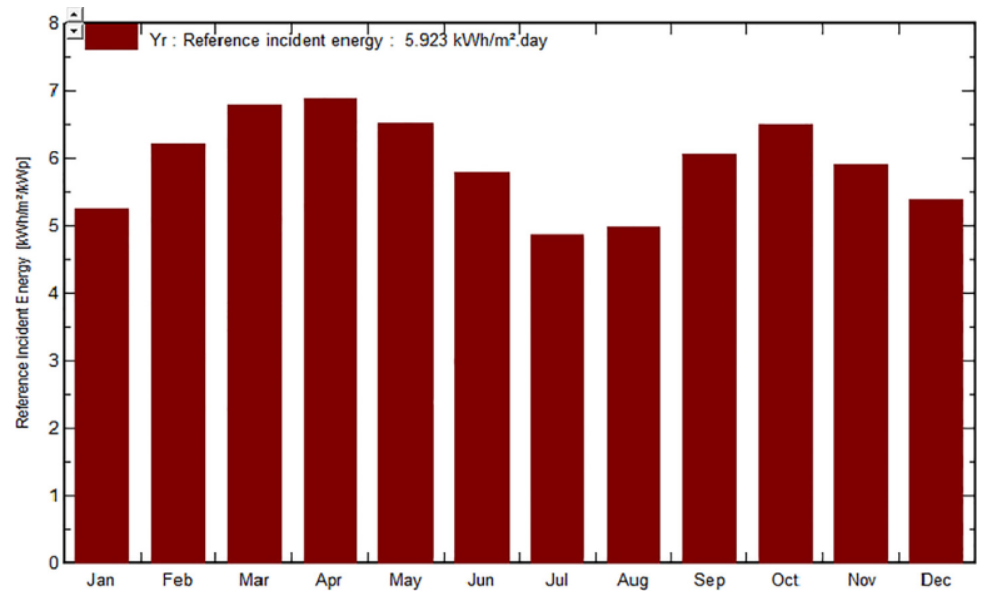

Figure 7 : Reference incident energy on collector

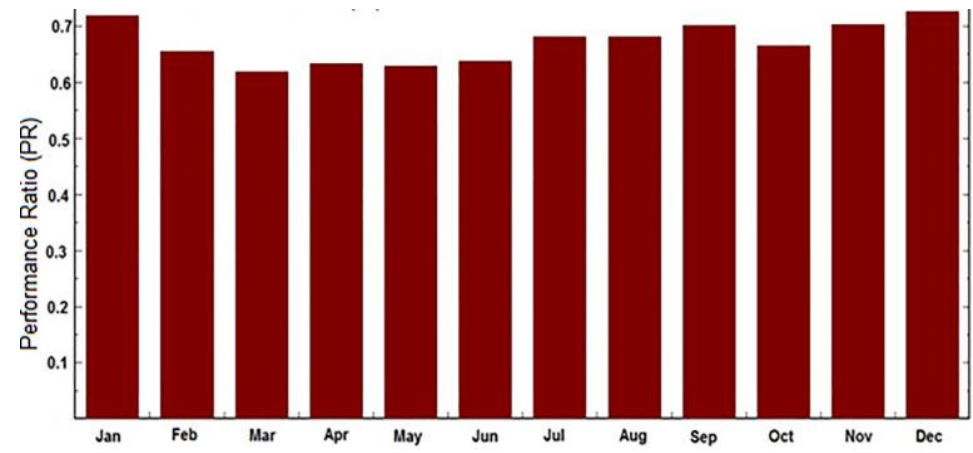

Figure 8 : Performance ratio of other system

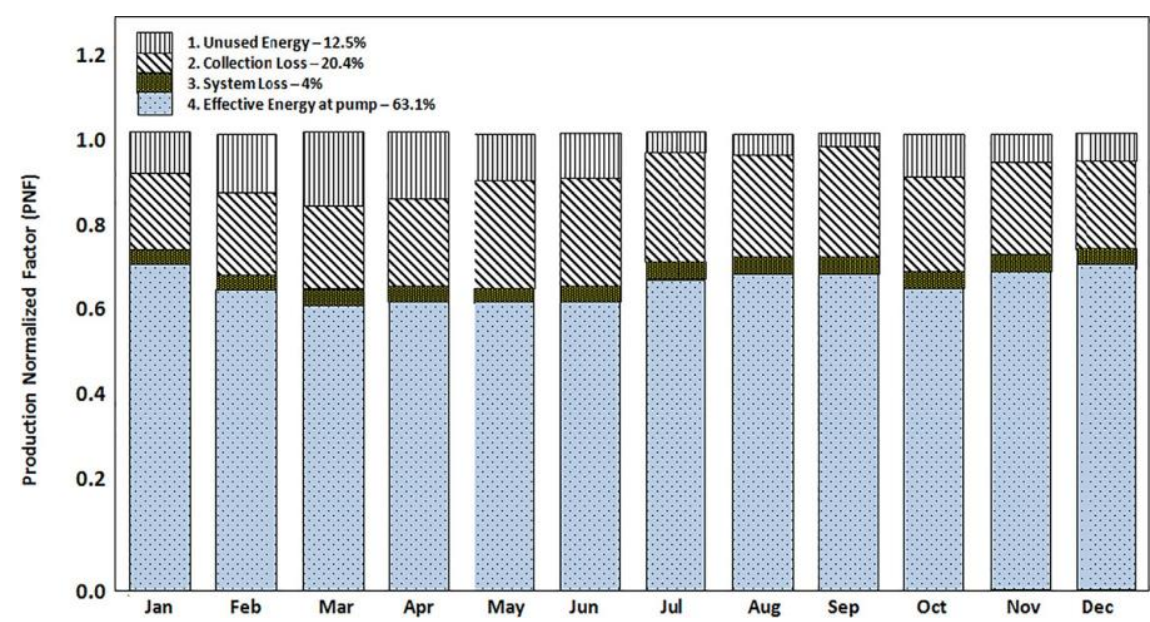

Figure 9 : Normalized production and loss factors distribution: Nominal Power 5100 w. 
Loss Diagram over the whole Year

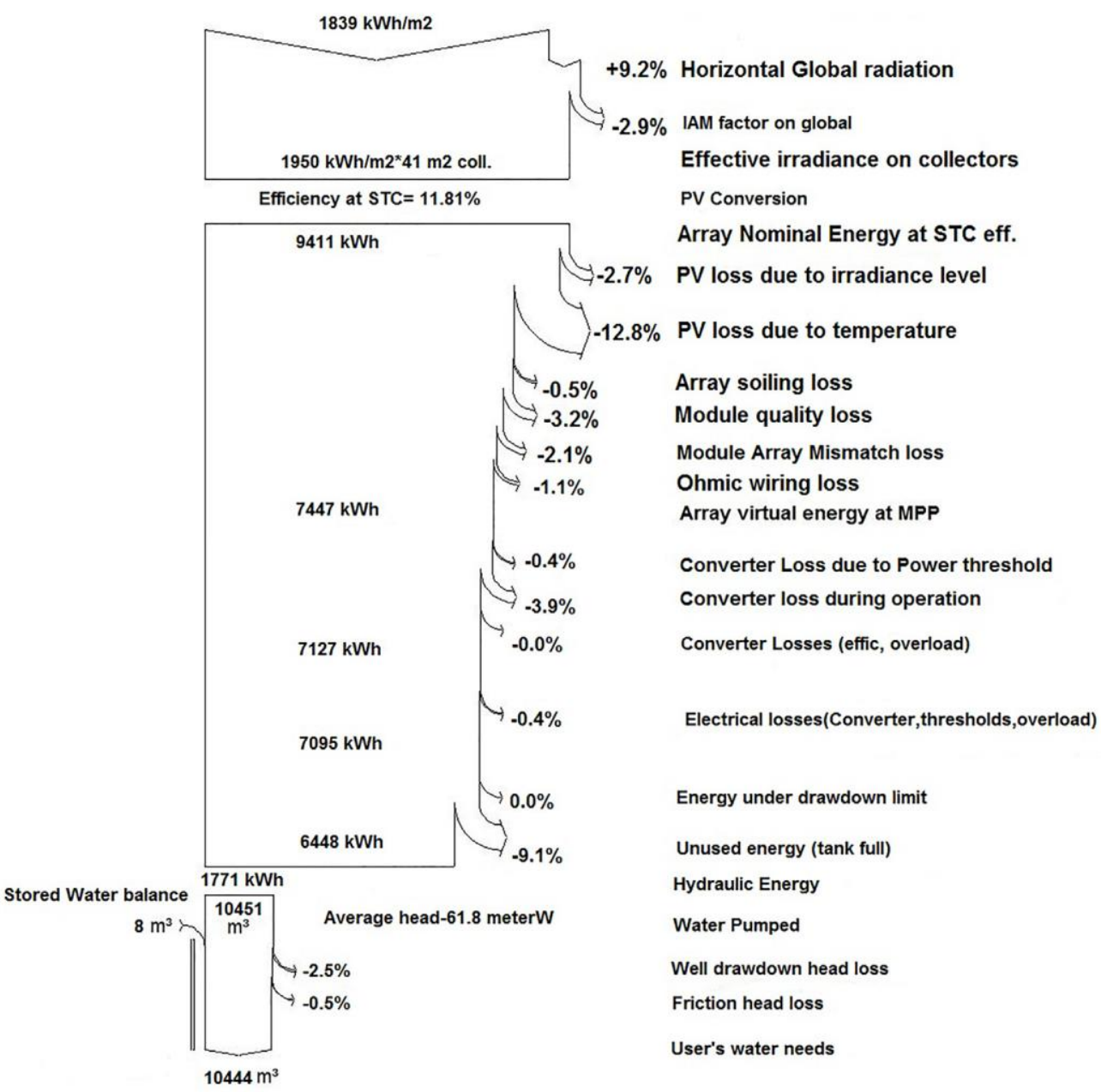

\subsubsection{Normalized production and loss factors}

This result shows cumulative analysis of total production from PV array and the different loss factors during power generation. The power generation and losses of system are represented in bar chart with different color to understand system (Figure 9).

\subsubsection{Flow rate function of pump power}

This diagram shows relation between energy availability at pump and flow rate of the pump. As the energy available at pump will increase the water flow rate of pump will also increase (Figure $10)$.

\subsubsection{Loss diagram}

- The loss diagram helps to identify quality of solar water pumping system design with a quick and insight look. The losses which are represented in loss diagram are temperature loss, soiling loss, module quality loss, mismatch loss, wiring loss, conversion loss etc. This loss result can be analyzed further for improvement of system efficiency (Figure 9). 


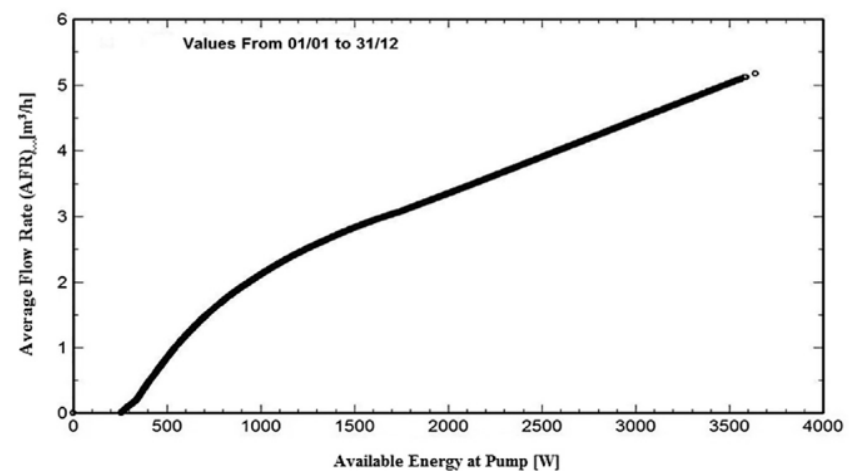

Figure10. Flow rate function of pump power •

\section{Discussion on PV syst Surewan ensurs}

PVsyst simulation results helped to analyze design process through any software medium.

Pre-design development using software

helps to get predictions about possible outcomes for real time system.

The complete simulation analysis helps to understand software requirement in terms of parameters which are used to fill for designing the system.

PVsyst result showing system efficiency $82.50 \%$ and it proves the accuracy of design parameters which we chose during the designing process.

\section{Conclusion}

This study presents simplified design optimization approach for Solar PV Water Pumping (SPVWP) System with the help of theoretical computations and PVsyst simulation software. In the solar pumping system analysis, theoretical computation approach facilitates in estimating design and performance parameters and PV syst simulation approach facilitates to understand effects of selected parameters on performance of the system. The results of PVsyst software are very useful for performance evaluation analysis and to understand complete step by step process of system.

different parameters on system performance and also helps to understand interrelation between two parameters.

Sankey diagram of result shows energy flow and losses of the system. This loss result can be analyzed further for improvement of system efficiency.

Economic calculation using PVsyst helps to understand cost analysis of system by taking different financial parameters in consideration. This analysis gives result about per $\mathrm{m} 3$ water to understand design mechanism of solar water pumping system with simplified computational approach. Pre design development of system using simulation software may assist to understand pre- dictions about possible outcomes for real time on field system and results can be analyzed further for improvement of system performance by comparative technical and economical assessment.

\section{References}

[1] C. Bibin, K. Vinoth Kumar, D. Muruga Pandi, R. Rup Chander, Fabrication of an off-road hybrid vehicle, Int. J. Trendy Res. Eng. Technol. 1 (1) (2017) 4-6.

[2] N. Kanthavelkumaran, P. Seenikannan, C. Bibin, Investigational study and manage the poisonous emissions in IC Engines by nano materials, Life Sci. J. 10 (3) (2013) 102-107.

[3] C. Bibin, C. Vinoth Kumar, N. Manoj Kumar, A. Naveen, Energy analysis of a DI diesel engine fueled with punnai oil methyl ester and its diesel blends, Int. J. Trendy Res Eng. 
Technol. 2 (5) (2018) 12-18.

[4] S. Gopinath, P. Devan, M. Balasubramanian, C. Bibin, Experimental study and optimization of injection parameters for a biodiesel using Taguchi method, Int. J. Appl. Eng. Res. 9 (26) (2014) 9292-9296.

[5] V. Dillibabu, N. Aravindhan, M. Krishnakumar, C. Bibin, Agglomeration in fluidized bed combustion system, IJSRD - Int. J. Sci. Res. Dev. 5 (03) (2017) 103-107.

[6] C. Bibin, K. Kishore, K. Baskar, J. Akshay Sharma, Performance analysis of a diesel engine fueled with punnai oil methyl ester and its diesel blends, Int. J. Trendy Res Eng. Technol. 2 (5) (2018) 74-79.

[7] S. Gopinath, C. Bibin, P.K. Devan, M. Balasubramanian, Performance and combustion characteristics test on VCR diesel engine, Int. J. Appl. Eng. Res. 10 (11) (2015) 1047110473.

[8] C. Bibin, P. Seeni Kannan, P. Devan, R. Rajesh, "Performance and emission characteristics of a DI diesel engine using diestrol blends and diesel as, fuel" (2019).

[9] S. Gopinath, C. Bibin, N. Dineshbabu, V. Bala Murugan, Optimizing the various parameters for biodiesel production by transesterification, Int. J. Eng. Res. Technol. 4 (02) (2015) 716-718.

[10] C. Bibin, P. Seenikannan, N. Kanthavelkumaran, Study on waste heat recovery in an internal combustion engine, Int. J. Eng. Res. Technol. 1 (10) (2012) 1-4.

[11] C. Bibin, P. Seenikannan, Thermal analysis of exhaust waste heat recovery from Diesel Engines, Int. J. Appl. Eng. Res. 9 (26) (2014) 9412-9415.

[12] C. Bibin, P. Seeni Kannan, P.K. Devan, Performance, emission and combustion characteristics of a DI diesel engine using blends of punnai oil biodiesel and diesel as fuel, Therm. Sci. 24 (1A) (2020) 13-25.

[13] C. Bibin, Emission control in CI engine using ethanol emulsion, Int. J. Trendy Res. Eng. Technol. 3 (4) (2019) 22-29.

[14] C. Bibin, A. Sivananth, S. Sivaneshwaran, A. Vignesh, B. Venkatesh, Experimental investigation on performance analysis of blends of two different methyl esters as fuel in CI engine, Int. J. Trendy Res. Eng. Technol. 2 (5) (2018) 64-69.

[15] C. Bibin, P. Seenikannan, Experimental analysis of energy recovery from an internal combustion engine exhaust using Rankine cycle, Adv. Mater. Res. 768 (2013) 158-163.

[16] D.L. Fenton, G.H. Abernathy, G.A. Krivokapich, J.V. Otts, Operation and evaluation of the Willard solar thermal power irrigation system, Sol. Energy 32 (6) (1984) 735-751.

[17] B. Eker, solar powered water pumping system - Google Search, Trakia J. Sci. 3 (7) (2005) 6-11.

[18] F. Cuadros, F. López-Rodríguez, A. Marcos, J. Coello, A procedure to size solar- powered irrigation (photoirrigation) schemes, Sol. Energy 76 (4) (2004) 465- 473.

[19] R. Kumar Harishankar, S.K.P. Sathish, U. Vignesh, T. Viveknath, Solar Powered Smart Irrigation System, Adv. Electron. Electr. Eng. 4 (4) (2014) 341-346.

[20] T. J. Kardos, C. A. Us, and D. Paul, "Patent Application Publication Pub. No.: US 2010 / 0249488 A1," vol. 1, no. 19, 2010.

[21] M. Dursun, S. Ozden, Application of solar powered automatic water pumping in Turkey, Int. J. Comput. Electr. Eng. (2012) 4-8.

[22] J. Burney, L. Woltering, M. Burke, R. Naylor, D. Pasternak, Solar-powered drip irrigation enhances food security in the Sudano-Sahel, Proc. Natl. Acad. Sci. U.S. A 107 (5) (2010) $1848-1853$.

[23] R. Sharma, S. Sharma, S. Tiwari, Design optimization of solar PV water pumping system, Mater. Today:. Proc. (2019).

[24]E. Gupta, The impact of solar water pumps on energy-water-food nexus: Evidence from Rajasthan, Energy Policy 129 (2019,) 598-609.

[25]K.M. Bataineh, Optimization analysis of solar thermal water pump, Renew. Sustain. Energy Rev. 55 (2016) 603-613.

${ }^{[26]}$ C. Kutlu, Y. Zhang, T. Elmer, Y. Su, S. Riffat, A simulation study on performance improvement of solar assisted heat pump hot water system by novel controllable crystallization of supercooled PCMs, Renew. Energy 152 (2020) 601-612.

[27]S.S. Chandel, M. Nagaraju Naik, R. Chandel, Review of solar photovoltaic water pumping 
system technology for irrigation and community drinking water supplies, Renew. Sustain. Energy Rev. 49 (2015) 1084-1099.

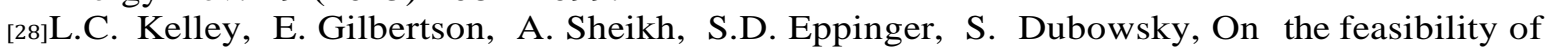
solar-powered irrigation, Renew. Sustain. Energy Rev. 14 (9) (2010) 2669-2682.

${ }^{[29]}$ E. Baifus Manke et al., Wind drift and evaporation losses of a mechanical lateral-move irrigation system: oscillating plate versus fixed spray plate emitters, Agric. Water Manage. 225 (2019).

[30] S. Roblin, Solar-powered irrigation: A solution to water management in agriculture, Renew. Energy Focus 17 (5) (2016) 205-206.

[31] A. A. Al-sewari, K.Z. Zamli, 8th International Conference on Robotic, Vision, Signal Processing and Power Applications," vol. 398, no. February, pp. 255-263, 2014.

[32] B. Gupta, R. Sharma, P. Shankar, P. Baredar, Performance enhancement of modified solar still using water emitter: An experimental approach, Perspect. Sci. 8 (2016) 191-194.

[33] Y. Bakelli, A. Hadj Arab, B. Azoui, Optimal sizing of photovoltaic pumping system with water tank storage using LPSP concept, Sol. Energy 85 (2) (2011) 288-294.

[34] R.J. Chilundo, D. Neves, U.S. Mahanjan, Photovoltaic water pumping systems for horticultural crops irrigation: advancements and opportunities towards agreen energy strategy for Mozambique, Sustain. Energy Technol. Assess. 33 (2019) 61-68.

[35] Vinayak Shinde, Sarika Wandre, Solar photovoltaic water pumping system for irrigation: a review, Afr. J. Agric. Res. 10 (22) (2015) 2267-2273. 